\begin{tabular}{|c|c|c|c|c|c|c|c|c|c|c|}
\hline \multirow{2}{*}{72} & & $\mathrm{E}$ & $E$ & $\mathrm{~N}$ & 7 & 9 & 4 & Dispatch: 08.06 .06 & Journal: EEN & \\
\hline & Journal Name & & & \multicolumn{4}{|c|}{ Manuscript No. } & Author Received: & No. of pages: 4 & ME: Arnold \\
\hline
\end{tabular}

Ecological Entomology (2006) 31, 1-4

\title{
Body size changes in ground beetle assemblages - a reanalysis of Braun et al. (2004)'s data
}

\author{
G Á B O R L . L Ö V E I ${ }^{1}$ and T I B O R M A G U R A ${ }^{2}{ }^{1}$ Department of Integrated Pest Management, Danish \\ Institute of Agricultural Sciences, Flakkebjerg Research Centre, Denmark, ${ }^{2}$ Hortobágy National Park Directorate, Debrecen, POB. \\ 216, H-4002, Hungary
}

\begin{abstract}
Data in Braun et al.'s (2004) recent paper on size trends in ground beetles (Carabidae) are re-analysed, after re-classifying the species according to feeding categories.

2. When ground beetles are classified as predatory species, mixed feeders or herbivores, and evaluated separately, the size trends indicate group-specific differences. Most of these do not support the efficiency-specialisation hypothesis.

3. Taxonomic groups rarely fit into one ecological category and ecological analyses should explicitly consider this hurdle.
\end{abstract}

Key words. Body size, Carabidae, disturbance, feeding type, life history, pollution.

\section{Introduction}

Size has a significant, substantial impact on ecological interactions (Peters, 1983). It modulates resource use, the outcome of species interactions (Peters, 1983), and more indirectly, the periods of activity, habitat suitability, and numerous other parameters. The study of size relationships and their role in shaping interactions is an active research area in ecology (Peters, 1983; Brown, 1995).

Changes in either the size in individual species, or the size distribution of the species in a habitat are also parameters potentially indicating environmental stress (McGeoch, 1998). Recently, Braun et al. (2004) used this approach to analyse species size trends in ground beetles (Carabidae) at an abandoned fertiliser factory in Germany. Using the mean size (estimated biovolume) of beetles present, they found that the average species size decreased over time (16 years), in parallel with a decrease in habitat contamination caused by the former fertiliser factory. Based on these results, they speculated about the validity of two conflicting hypotheses of resource use distribution within the family of ground beetles (Carabidae). In Braun et al.'s study (2004) ground beetles were used as a taxonomic (and predatory) group; no consideration was made of the various feeding strategies that are found within the group.

In the present contribution the results by Braun et al. (2004) are reconsidered and their data were subjected to an evaluation

Correspondence: Gabor L. Lövei, Department of Integrated Pest Management, Danish Institute of Agricultural Sciences, Flakkebjerg Research Centre, DK-4200 Slagelse, Denmark. E-mail: gabor.lovei@ agrsci.dk that considered feeding habits of the species. The main motivation for this was that an important assumption, the uniform feeding type of ground beetles, is not correct. Neither all ground beetles, nor even the majority of them can be considered predatory. In the European fauna, there are many species that are herbivores, or mixed feeders (Lövei and Sunderland, 1996). A final point is that one of the hypotheses evaluated by Braun et al. (2004) and attributed to Blake et al. (1994), in fact was suggested earlier by Szyszko (1983).

\section{Materials and methods}

Data presented in Braun et al. (2004) were re-analysed after resorting their species list into three adult feeding categories: predatory species, mixed feeders, and herbivores. This categorisation was based on work by Larochelle (1990), Hùrka (1996), and Lindroth $(1985,1986)$. We then re-analysed size change trends using the same methods as Braun et al. (2004) but chose a different graphical representation.

Size trends were analysed using ANOVA, followed by Tukey tests if significant differences were found. Calculations were done using the SPSS statistical software (SPSS, 2000).

\section{Results}

Size trends of all species

Considering all carabids together (regardless of their feeding categories), the mean size in the 90 s was significantly smaller 
than that in the 80s for all the studied areas (Fig. 1 and Table 1; see also fig. 3 and table 2 in Braun et al., 2004). This picture changed when the species in the different feeding categories were considered separately.

\section{Analysis by feeding categories}

Carnivore species. In the severely polluted area, body size was smallest in 1991, significantly smaller than either in 1980 and 1996 (but not 1990). The other three body size values did not significantly differ from each other, although 1981 was smaller than either 1980 or 1996 (Fig. 1 and Table 1).

In the moderately polluted area, there is a decreasing trend, but this consists only of a drop from the first year's higher value to a lower level in the following year. Ten years later, this level is somewhat lower, now becoming significantly smaller than the corresponding value for 1980 (but not the more variable 1981). This level shows virtually no difference 5 years later (Fig. 1 and Table 1).

In the lightly polluted area, there are no significant time trends. The mean size in 1980 was somewhat larger than in the other 3 years (Fig. 1 and Table 1).

Herbivore species. There were few herbivorous species. The size trend in the severely polluted area showed a zigzag pattern, with some significant differences in the middle years. The initial and final years did not differ. The same appeared in the other two areas, at a somewhat lower level (Fig. 1 and Table 1).

Mixed feeder species. The largest number of species were classified as mixed feeders, and, consequently, this group should contribute considerably to the overall trend. In fact, the trends shown by the mixed feeders were similar to that of 'all species'. This group shows no significant size difference among the dif- ferently polluted areas in 1980 or 1981 . Severely and moderately polluted areas seem to support assemblages that became progressively smaller, more in the severely polluted than in the moderately polluted area. There was no decreasing trend in the lightly polluted area, except a smaller assemblage in 1991 (Fig. 1 and Table 1).

\section{Discussion}

This re-analysis further developed the conclusions of Braun et al. (2004). Most of the support for the role of the increasing specialisation hypothesis in the organisation of ground beetle assemblages disappears when the feeding behaviour of the species is taken into account.

Our analysis underlines the notion that taxonomic units rarely correspond to ecological units, and it is rarely justified to consider them as such. Considering the mean size of ground beetles in general may give rise to a statistical artefact. This is due to the oversimplified classification of the family as predators. Considering natural history is essential for the correct ecological interpretation of patterns in nature. Carabids can conveniently be collected by a single method as most of the species, at least in the northern temperate region (but not in the tropics, see Erwin, 1979), have surface-active adults. Traditionally, carabids have been considered predators, but even Thiele (1977) stressed that this can be a misleading simplification. Results published since the early 70s fully support this suggestion (Lövei and Sunderland, 1996; Toft and Bilde, 2002). Consequently, the approach followed by Braun et al. (2004) is of limited value, and in need of further development. The different feeding types of ground beetles should be considered separately and it was demonstrated that this indeed changed the time-size relationship. It is ecologically more valid to consider the changes in size and the assumed resource partitioning with at least

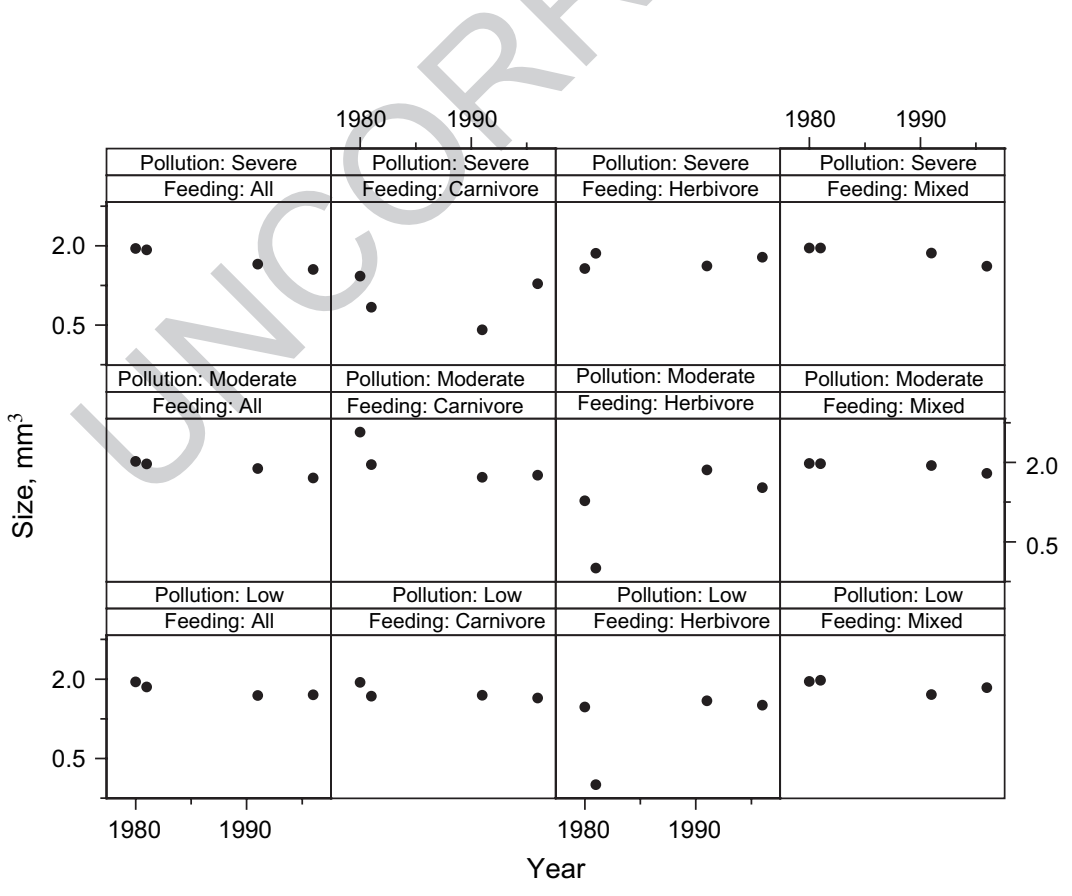

Fig. 1. Size trends (biovolume, $\mathrm{mm}^{3}$ ) of ground beetle species captured in three areas under different pollution levels near a fertiliser factory, Germany, in 4 years between 1980 and 1996. Data from Braun et al. (2004). 
Table 1. Results of the one-way ANOva for the ground beetle species collected in the severely, moderately, and lightly polluted areas in 1980, 1981, 1991, and 1996, near a fertiliser factory, Germany. Data from Braun et al. (2004)

\begin{tabular}{|c|c|c|c|c|c|c|}
\hline Source & SS & d.f. & MS & $F$ & $P$ & Tukey-test \\
\hline \multicolumn{7}{|c|}{ All species, severely polluted area } \\
\hline Year & 79.855 & 3 & 26.618 & \multirow[t]{3}{*}{93.023} & \multirow[t]{3}{*}{$<0.001$} & \multirow{3}{*}{$1980=1981>1991>1996$} \\
\hline Error & 1092.223 & 3817 & 0.286 & & & \\
\hline Total & 11937.437 & 3821 & & & & \\
\hline \multicolumn{7}{|c|}{ All species, moderately polluted area } \\
\hline Year & 7.279 & 3 & 2.426 & \multirow[t]{3}{*}{15.992} & \multirow{3}{*}{$<0.001$} & \multirow{3}{*}{$1980=1981=1991>1996$} \\
\hline Error & 71.312 & 470 & 0.152 & & & \\
\hline Total & 1647.199 & 474 & & & & \\
\hline \multicolumn{7}{|c|}{ All species, lightly polluted area } \\
\hline Year & 4.588 & 3 & 1.529 & \multirow[t]{3}{*}{9.386} & \multirow{3}{*}{$<0.001$} & \multirow{3}{*}{$1980>1991 ; 1980>1996$} \\
\hline Error & 118.786 & 729 & 0.163 & & & \\
\hline Total & 2311.356 & 733 & & & & \\
\hline \multicolumn{7}{|c|}{ Carnivore species, severely polluted area } \\
\hline Year & 68.275 & 3 & 22.758 & \multirow[t]{3}{*}{56.302} & \multirow{3}{*}{$<0.001$} & $1980>1991 ; 1996>1991$ \\
\hline Error & 191.194 & 473 & 0.404 & & & \\
\hline Total & 794.861 & 477 & & & & \\
\hline \multicolumn{7}{|c|}{ Carnivore species, moderately polluted area } \\
\hline Year & 4.069 & 3 & 1.356 & \multirow[t]{3}{*}{3.976} & \multirow[t]{3}{*}{0.009} & $1980>1991 ; 1980>1996$ \\
\hline Error & 48.440 & 142 & 0.341 & & & \\
\hline Total & 521.016 & 146 & & & & \\
\hline \multicolumn{7}{|c|}{ Carnivore species, lightly polluted area } \\
\hline Year & 0.942 & 3 & 0.314 & \multirow[t]{3}{*}{1.465} & 0.224 & \\
\hline Error & 66.863 & 312 & 0.214 & & & \\
\hline Total & 956.640 & 316 & & & & \\
\hline \multicolumn{7}{|c|}{ Herbivore species, severely polluted area } \\
\hline Year & 4.155 & 3 & 1.385 & 24.174 & $<0.001$ & $1996>1991$ \\
\hline Error & 50.995 & 890 & 0.057 & & & \\
\hline Total & 2497.278 & 894 & & & & \\
\hline Herbivor & ecies, moder & polluted & & & & \\
\hline Year & 4.923 & 3 & 1.641 & 30.136 & $<0.001$ & $1991>1996$ \\
\hline Error & 4.847 & 89 & 0054 & & & \\
\hline Total & 249.327 & 93 & & & & \\
\hline Herbivor & ecies, lightly & ted area & & & & \\
\hline Year & 2.430 & 3 & 0.810 & 12.819 & $<0.001$ & not performed $*$ \\
\hline Error & 4.423 & 70 & 0.063 & & & \\
\hline Total & 175.991 & 74 & 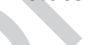 & & & \\
\hline Mixed fe & g species, se & pollut & & & & \\
\hline Year & 51.720 & 3 & 17.240 & 72.583 & $<0.001$ & $1980>1991 ; 1980>1996,1981>1996,1991>1996$ \\
\hline Error & 580.979 & 2446 & 0.238 & & & \\
\hline Total & 8645.298 & 2450 & & & & \\
\hline Mixed fe & g species, $\mathrm{m}$ & tely pol & area & & & \\
\hline Year & 1.447 & 3 & 0.482 & 9.555 & $<0.001$ & $1980=1981=1991>1996$ \\
\hline Error & 11.713 & 232 & 0.050 & & & \\
\hline Total & 876.856 & 236 & & & & \\
\hline Mixed fe & ig species, lig & polluted & & & & \\
\hline Year & 3.370 & 3 & 1.123 & 9.220 & $<0.001$ & $1980=1981=1996>1991$ \\
\hline Error & 41.419 & 340 & 0.122 & & & \\
\hline Total & 1178.725 & 344 & & & & \\
\hline
\end{tabular}

*Too few individuals in 1980 and 1981.

the different feeding types separately. The assumptions of feeding categories are crucial, and future studies refining these categories (for example, the extent of carrion feeding in carabids, which currently is not well understood, Lövei and Sunderland, 1996) might lead to still different results.
When seeking explanations for assemblage organisation, single-group studies can lead to spurious results. In the case of carabids, spiders and ants should be considered, as they have a significant impact on ground beetles (Thiele, 1977; Lövei and Sunderland, 1996). 
A further, modulating influence on assemblage organisation is the permanence of species in a habitat. Species presence is often taken as an indication that the species can find all its needs and survive in the habitat. The presence of non-resident species, termed tourists, transient or occasional species in ecological communities, however, is frequent (Magurran, 2003). Such species do not have sufficiently tight links to the habitat where found, and even though their ratio can be high (Novotny and Missa, 2000), they are not legitimate members of the ecological community. Considering all species captured as integral components of the ecosystem is debatable. Species presence is not necessarily permanent, and community organisation could be better understood if permanent and transient species are identified and separated (Magurran and Henderson, 2003). The latter may have little explanatory power in the search for assembly and resource distribution patterns (Magurran, 2003). Size trends could be different also in this case if we could separate permanent from temporary species in the present case but this is not possible due to the non-continuous sampling.

Braun et al. (2004) termed the hypothesis that increasing disturbance causes the average size of ground beetles to decrease in a habitat as 'Blake et al. hypothesis'. The same idea, although formulated a little differently, was suggested in 1983 by Jan Szyszko, who studied the possibility of characterising pine forest regeneration by using an index of 'mean individual biomass' (Szyszko, 1983). His hypothesis, while formulated as 'decreasing disturbance allows greater average body size', is essentially the same as in Blake et al. (1994). Therefore, in accordance with scientific priority, we suggest that this hypothesis should be termed the 'Szyszko-hypothesis', or 'increasing average size hypothesis'.

\section{Acknowledgements}

We thank Drs A. Báldi, B. Hawkins, J. Kotze, B. Tóthmérész, and three anonymous reviewers for comments on earlier drafts of the manuscript.

\section{References}

Blake, S., Foster, G.N., Eyre, M.D. and Luff, M.L. (1994) Effects of habitat type and grassland management practices on the body size distribution of carabid beetles. Pedobiologia, 38, 502-512.

Braun, S.D., Jones, T.H. and Perner, J. (2004) Shifting average body size during regeneration after pollution - a case study using ground beetle assemblages. Ecological Entomology, 29, 543-554.
Brown, J.H. (1995) Macroecology. University of Chicago Press, Chicago, Illinois.

Cleveland, W.C. (1994) The Elements of Graphing Data. Hobart Press, Summit, New Jersey.

Erwin, T.L. (1979) Thoughts on the evolutionary history of ground beetles: hypotheses generated from comparative faunal analysis of lowlane forest sites in temperate and tropical regaions. Carabid Beetles: Their Evolution, Natural History, and Classification (ed. by T. L. Ervin, G. E. Ball, D. R. Whitehead and A. L. Halpern), pp. 539-592. Junk Publishers, The Hague.

Hùrka, K. (1996) Carabidae of the Czech and Slovak Republics. Kabourek, Zlin, Czech Republic.

Larochelle, A. (1990) The food of carabid beetles. Fabreriessupplement, 5, 1-132.

Lindroth, C.H. (1985) The Carabidae (Coleoptera) of Fennoscandia and Denmark. Fauna Entomologica Scandinavica, 15, part 1. E.J. Brill, Leiden, The Netherlands.

Lindroth, C.H. (1986) The Carabidae (Coleoptera) of Fennoscandia and Denmark. Fauna Entomologica Scandinavica, 15, part 2. E.J. Brill, Leiden, The Netherlands.

Lövei, G.L. and Sunderland, K.D. (1996) Ecology and behavior of ground beetles (Coleoptera: Carabidae). Annual Review of Entomology, 41, 231-256.

Magurran, A.E. (2003) Measuring Biological Diversity. Oxford University Press, Oxford.

Magurran, A.E. and Henderson, P.A. (2003) Explaining the excess of rare species in natural species abundance distributions. Nature, 422, 714-716.

McGeoch, M.A. (1998) The selection, testing, and application of terrestrial insects as bioindicators. Biological Reviews, 73, 181-201.

Novotny, V. and Missa, O. (2000) Local versus regional species richness in tropical insects: one lowland site compared with the island of New Guinea. Ecological Entomology, 25, 445-451.

Peters, R.H. (1983) The Ecological Implications of Body Size. Cambridge University Press, Cambridge.

SPSS Inc. (2000) SPSS 10.0.7 for Windows. SPSS Inc., Chicago, Illinois.

Szyszko, J. (1983) State of Carabidae (Col.) fauna in fresh pine forest and tentative valorisation of this environment. SGGW-AG Monographs No. 28. Warsaw Agricultural University Press, Warsaw, Poland.

Thiele, H.-U. (1977) Carabid Beetles in Their Environments. Springer, Berlin.

Toft, S. and Bilde, T. (2002) Carabid diets and food value. The Agroecology of Carabid Beetles (ed. by J. M. Holland), pp. 81-110. Intercept, Andover, U.K.

Tufte, E.R. (2003) The Visual Display of Quantitative Information, 2nd edn. Graphics Press, Cheshire, Connecticut.

Accepted ????? 2005 


\section{Author Query Form}

\section{Journal: Ecological Entomology}

\section{Article: een_794.xml}

Dear Author,

During the copy-editing of your paper, the following queries arose. Please respond to these by marking up your proofs with the necessary changes/additions. Please write your answers on the query sheet if there is insufficient space on the page proofs. Please write clearly and follow the conventions shown on the attached corrections sheet. If returning the proof by fax do not write too close to the paper's edge. Please remember that illegible mark-ups may delay publication. Many thanks for your assistance.

Query No.

Query

Remark 


\section{Please correct and return this set}

Please use the proof correction marks shown below for all alterations and corrections. If you wish to return your proof by fax you should ensure that all amendments are written clearly in dark ink and are made well within the page margins.

\begin{tabular}{|c|c|c|}
\hline Instruction to printer & Textual mark & Marginal mark \\
\hline Leave unchanged & ... under matter to remain & Stet \\
\hline $\begin{array}{l}\text { Insert in text the matter } \\
\text { indicated in the margin }\end{array}$ & $h$ & New matter followed by \\
\hline Delete & $\mapsto$ through matter to be deleted & $\delta$ \\
\hline Delete and close up & E through matter to be deleted & की \\
\hline $\begin{array}{l}\text { Substitute character or } \\
\text { substitute part of one or } \\
\text { more word(s) }\end{array}$ & $\begin{array}{l}/ \text { through letter or } \mapsto \text { through } \\
\text { word }\end{array}$ & New letter or new word \\
\hline Change to italics & - under matter to be changed & لس \\
\hline Change to capitals & $\equiv$ under matter to be changed & $\equiv$ \\
\hline Change to small capitals & $=$ under matter to be changed & $=$ \\
\hline Change to bold type & m under matter to be changed & $m$ \\
\hline Change to bold italic & $\bar{\approx}$ under matter to be changed & 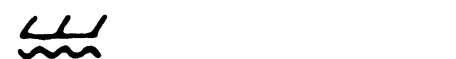 \\
\hline Change to lower case & Encircle matter to be changed & $\#$ \\
\hline Change italic to upright type & (As above) & \\
\hline Insert 'superior' character & $\begin{array}{l}/ \text { through character or } \wedge \text { where } \\
\text { required }\end{array}$ & $\begin{array}{l}\text { y under character } \\
\text { e.g. } 2 y\end{array}$ \\
\hline Insert 'inferior' character & (As above) & $\boldsymbol{L}$ over character e.g. $\mathbf{2}$ \\
\hline Insert full $\mathrm{s}$ & (As abc & ○ \\
\hline Insert comma & (As above) & , \\
\hline Insert single quotation marks & (As abo & $y$ and/or $y$ \\
\hline $\begin{array}{l}\text { Insert double quotation } \\
\text { marks }\end{array}$ & (As above) & $\ddot{y}$ and/or $y$ \\
\hline Insert hyphen & (As : & (4y) \\
\hline Start new paragraph & $\sqrt{-10}$ & $\overline{5}$ \\
\hline No new paragraph & 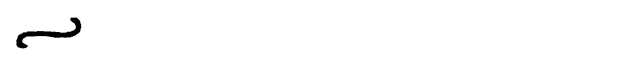 & 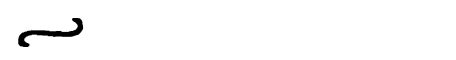 \\
\hline Transpose & حـ & 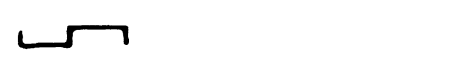 \\
\hline Close up & linking : & $=$ \\
\hline Insert space between letters & $\boldsymbol{h}$ between letters af & $\#$ \\
\hline Insert space between words & $\boldsymbol{h}$ between words affected & $\#$ \\
\hline Reduce space between letters & $\uparrow$ between letters affected & $T$ \\
\hline Reduce space between words & $\tau$ between words affected & \\
\hline
\end{tabular}

